of ovarian tumours are lucid and in spite of many references to other sources, steer a clearly understood path through the maze that traps so many postgraduate students.

The section on gynaecological operations could only have been written by men who are as good technical masters as the authors are; and who have been teaching surgery for years.

Use has been made of the drawings of Victor Bonney, and since both authors were pupils of the great Bonney, the operative technique described derives from his, but there are many modern advances added.

The book is detailed in the extreme. It was a pleasure for instance to find more than one page devoted to true hydatid tumours, when the reviewer had unexpectedly found one at laparotomy. Yet the book is certainly not encumbered with unnecessary reading material.

The reproduction of the diagrams is, in the main, excellent, although perhaps a little more pruning of some of the old illustrations might have been carried out because they do add to the price; yet the work is remarkable value, and is probably now a 'must' for the M.R.C.O.G.

But why did the publishers produce such a dull dust jacket for such a brilliant book ?

E.E.P.

\section{CLINICAL ASPECTS OF THE AUTONOMIC NERVOUS SYSTEM}

By L. A. Gillilan, Ph.D., M.D. Pp. xii +316 , with 42 illustrations. London: J. \& A. Churchill Ltd. 1955. 45s.

Professor Gillilan has given us a most interesting account of the anatomy of the autonomic nervous system. He has demonstrated a number of important consequences arising from the anatomy of this part of the nervous system. The presentation and printing are excellent and it is easy to look up the neuro-anatomy of any particular region. A wide range of references is given.

It is surprising perhaps that some rather fundamental work has been omitted from the text, such as Lewis's work on referred pain, and the work of Guttmann and Whitteridge on afferent pathways from the bladder, or the work of Harris and others on the hypothalamic control of some pituitary mechanisms. One finds, too, some feeling of confusion in the use of the works 'sympathetic' and 'para-sympathetic,' although the author does himself draw attention to some paradoxes involved in the ordinary use of these terms. There are instances in which perhaps the explanations given of clinical phenomena are a little over-simplified. The view is expressed that there is a vaso-constrictor sympathetic inflow and a vaso-dilator para-sympathetic inflow, and this view of the control of the peripheral blood vessels is, if correctly interpreted by the reviewer, most unorthodox.

This book will be of considerable interest to most medical men and in particular to those who have special interest in the autonomic nervous system. $\stackrel{\mathbb{D}}{\mathcal{Q}}$

K.E.C.

\section{MAN IN A COLD ENVIRONMENT}

By Alan C. Burton, Ph.D. and Otto G. Edholm, 을 M.B., B.S. Pp. xiv +273 , with 75 illustrations. London: Edward Arnold Ltd. 1955. 3os."

Over the past quarter of a century a great deal of knowledge has been accumulating on the physio- logical responses of man to his environment. Little. of this information has so far reached the standard $\vec{A}$ textbooks and most of that which has done so is $\vec{\rho}$ made up of rather dogmatic half-truths. The time was therefore ripe for a more detailed account of some aspects of body temperature regulation in man. The authors of this book have set themselves the $\omega$ difficult task of reviewing a very wide field of work. They have rightly used a considerable space in $N$ reviewing and describing the physical principles $\omega$ which must be common knowledge to anyone who? aspires to intelligent research in temperature regulation. Besides this, the physics of the designo of insulated clothing are discussed and this section? is presented in easily readable form. The remainderc of the book, which deals with the physiological responses to cold, is well written and contains a good $\overrightarrow{.}$ selection from the available literature. There age also within the book some very thought-provokikg philosophical discussions. The authors have dowe a good job in selecting the salient features from vast mass of literature and this book, because of the way in which the principles underlying temperature regulating mechanisms are discussed, should form part of the armament of anyone interested in body temperature regulation.

K.E.C.

\section{NEUROLOGY}

By S. A. KINNIER Wilson, M.A., M.D., D.Sc., $\frac{\partial}{3}$ F.R.C.P. Edited by A. Ninian BruCE, F.R.C.P., D.Sc., M.D., F.R.S. Second edition. Three Vols. Pp. xii, viii and viii $+2060+99$, with 279 . illustrations. London: Butterworth \& Co., Ltd. 1954. £10 ros. the set or $£ 3$ ros. per vol.

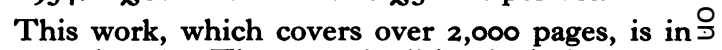
three volumes. The second edition includes a new $D$ chapter on aphasia, apraxia and agnosia, and the chapter on neurosyphilis has been modified. The N general character of the first edition has been undisturbed.

This is in many ways a remarkable book. The N historical field it covers is enormous; indeed, the $\omega$ text bristles with so many references as to become in places hard to follow. The style of writing is that of an age which has passed from medical $\mathbb{\infty}$ literature and the pages are larded with an abundance? of latin tags. The approach to the subject, too, is $\square$ somewhat dated, belonging to an era when toxins in ${ }^{\circ}$

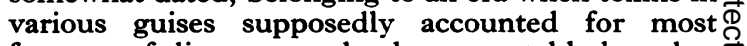
features of disease not clearly accountable by other $\mathbb{D}$ 